\title{
THE USE OF BRAND IMAGE CELEBRITY ENDORSER OF LUWAK WHITE COFFEE TO INCREASE THE PROFIT
}

\author{
(CASE STUDY ON VISITOR OF WAROENG KOPI ACEH MEDAN 2018) \\ Putra Chairy ${ }^{1}$, Adriansyah ${ }^{1}$ \\ Economy Faculty, Amir Hamzah University, Medan, Indonesia
}

\begin{abstract}
This study aims to analyze the influence of celebrity endorser, and brand image of purchase decisions on Luwak White Coffee customers. Purchasing decision is an important thing to do a company to find out how much consumer buying interest in Luwak White Coffee products with the added celebrity endorser. One way to gain competitive advantage in improving purchasing decisions is to form a good brand image in the eyes of consumers and easy to remember always. Data used in this study obtained from a questionnaire conducted in primary and some observation and direct interview with loyal customers Luwak White Coffee in Coffee shop Aceh Medan 2018. The analysis technique used is multiple regression using hypothesis test, that is $F$ test and $t$ test. This research can be concluded based on statistic test that variable celebrity endorser, and brand image together have a positive influence on the purchase decision variable. Based on the $t$ test, celebrity endorser, and brand image positively and significantly affects the purchasing decision. From this research obtained Adila $R$ square (R2) value of 0,75,8 $(75,5 \%)$ which means that the combination of celebrity endorser and brand image can explain the impact on the purchase decision which increase and the rest is influenced by other variable equal to $24,5 \%$.
\end{abstract}

Keywords: celebrity endorser; brand image; coffee; purchase 


\section{INTRODUCTION}

The era of free trade and globalization is now characterized by the widespread variety of products, both in the form of goods and services that cause business competition between companies getting tighter. This causes the company's management is required to more carefully address in determining the competitive strategy. Every company seeks to attract the attention (prospective) consumers in various ways one of them by providing information about product. The form of providing information about the product can be done through various forms of marketing communication programs including: advertising, sales promotions, personal selling, public relations and direct marketing. Advertising is one of the most common ways companies use to lead persuasive communication to a target. The medium used is most effective in affect consumers to make purchases and for products offered by marketers through advertising media has a special attraction for prospective customers to buy, it is necessary support of famous figures or ad stars as the delivery of messages in advertising. Based on this, companies should be able to plan an effective marketing strategy so that consumers can provide a positive response to the product. A marketing strategy that can be done by a company to communicate its products effectively in introducing its products to consumers and attracting attention through advertising. One of the advertising concept used by the company is with product endorser. Companies more often use celebrities to support their products in an advertisement than the average person.

A celebrity has the popularity, physical attraction, sexual attraction, courage, talent, authority that can serve as a lure for consumers to buy products that can increase sales. The use of celebrities as endorser products must go through a variety of considerations, including the level of popularity with the issue of whether the selected celebrity can represent the character of the product being advertised. (Royan, 2004) says that the characteristic endorser includes attractiveness, trustworthiness, and expertise. Attraction refers to intelligence, personality traits, lifestyle, physical attractiveness of the endorser. Trust can arise in the honesty, the integrity of the product and the trustworthiness of an endorser. Expertise refers to the knowledge, experience possessed by an endorser associated with its advertising. Marketing is a social and managerial 
process by which individuals and groups derive what they need and want by creating, offering and freely maintaining meaningful products and services for people other. Celebrity is someone who has fame and has special attributes that are attractive and reliable. (Silvera and Austad, 2004). The word celebrity refers to someone who is known to a wide audience who could have been a flem actor, musician, sports athlete, singer and entertainer and so on who are better known for having expertise in their respective fields. Brand image is a representation of the whole perceptions of the brand and shaped from past information and experience of the brand. The image of the brand relates to an attitude of belief and preference for a brand. Consumers who have a positive image of a brand, will be more likely to make a purchase. The consumer decision process does not end with a purchase, but continues until the purchase becomes an experience for consumers in using the purchased product and that experience will be a consideration for future purchasing decisions (Ma'ruf, 2005: 14). Purchasing decisions are a fundamental part of consumer behavior that leads to the purchase of products and services. In making a purchase decision, consumers are inseparable from the factors that influence and motivate consumers to make a purchase. From these factors consumers will make an assessment of the various alternative options and choose one or more alternatives that are required based on certain considerations. Meanwhile, according to Amirullah (2002: 61) decision-making is a process of assessment and selection of various alternatives in accordance with the interests of certain with set of corners option is considered most profitable. Consumer purchasing decisions are preceded by a buying desire that arises because there are various influential factors such as family income, desired price, profit or commonly obtained from the product in question. When consumers make a decision, mufins are common situational changes that affect the intensity of purchases.

\section{LITERATURE REVIEW}

\subsection{Coffee}

Coffee is a beverage that has been roasted coffee beans and mashed into powder. Coffee is one of the world's most cultivated commodities in more than 50 countries. Two common coffee 
tree varieties are Robusta Coffee (Coffea canephora) and Arabica Coffee (Coffea arabica). The processing of coffee before it can be drunk through a long process that is from the harvesting of coffee beans that have been cooked either by machine or by hand then done the processing of coffee beans and drying before it becomes coffee. The next process is penyangraian with varying degrees degree. After penyangraian coffee beans milled or smoothed into a coffee powder before coffee can be drunk. History records that the discovery of coffee as a nutritious drink and energized first times discovered by the Ethiopians in the African continent about 3000 years (1000 BC) ago. [5] Coffee then continues to grow until today became one of the most popular beverages in the world consumed by various circles of society [need referral] Indonesia alone has been able to produce more than 400 thousand tons of coffee per year. In addition to the flavor and aroma, coffee can also reduce the risk of cancer, diabetes, gall stones and heart disease.

\subsection{Customers}

Subscribers or subscriptions refer to individuals or households, companies that buy goods or services generated in the economy. Specifically, this word is often interpreted as someone who is accustomed to buy goods at a particular store. In various approaches, depending on the nature of the industry or culture, customers can be referred to as clients, customers, patients. The meaning is a third party outside the company system that for some reason, buy goods or services company. Especially for customers, this term is used to represent parties who use the services of banks, either for their own purposes or as an intermediary for the needs of others. In a business activity, a marketer or seller, approaches the prospect. Prospects are understood as business relationships that build relationships with companies. Prospects are relationships that can already be a customer or not. In a broader sense, business relationships relate to business relationships with all third parties outside the company. Included in this criteria: provider / vendor, bank, or other party. Customer needs can be defined as the goods or services it needs to achieve certain goals. Customers have different levels of demand and customer expectations are typically influenced by cultural values, advertising, marketing, and other forms of communication, both from suppliers and other sources. Customer needs and expectations can be determined through interviews, surveys, conversations, data mining or other information gathering methods. 
Customers may not have a clear understanding of their needs. Help for determining needs can be a valuable service for customers. In this process, expectations can be adjusted or adapted to the capabilities of a particular product or service.

\subsection{Brand}

Brand (brand) is one of the most important part of a product. Brand can be an added value for the product either in the form of goods or services. For example: If there are 2 (two) perfume bottles filled with the same type of perfume both in quality and quantity, then branded perfumes will be considered more valuable, better and better quality than unbranded perfumes. This added value is very profitable for producers or companies. That's why the company strives to continue to introduce the brands it has from time to time, especially consumers who become the target Supermarket The notion of a mark, "Brand" is a term, sign, symbol, design or combination of all of these that is intended to identify the product or service of a seller or group, which distinguishes the product / service from other products, especially rival products "(Kotler 1987, p 440).The elements of the brand are:

1Name

$2 . \log 0$

3.symbol

4.design

5.slogan

6. packaging

Some criteria must be considered in the selection of brand elements:

a. Easy to remember: This means that the selected brand element should be easy to remember, and called / spoken. Symbols, logos, names used should be interesting, unique to attract people's attention to remember and consume.

b. Has meaning: This means that brand elements should contain a meaning or explanation / description of the product. It is expected that this meaning can affect consumers to consume the product.

The description of the meaning contained can be: 
-general information about the category and content of the product

-information about important product-featured compositions and benefits of the product

c. Interesting and funny: Another approach to attract consumers is the unique, funny, variation of branding elements, the selection of elements rich in visualization and imagination. In this case the highlighted is an interesting design and funny.

d. Flexible: This means that brand elements can be understood and still acceptable by the region / market, even other cultures. The name used is not too difficult to translate. Often the selection of brand elements is easily remembered by local people, but it is very difficult to understand by other communities. This will certainly discourage manufacturers from entering into new markets.

e. Legal: This means that the brand element is legitimate under applicable law and law, so it is under legal protection.

The things that are closely related to the brand are:

1. Brand name (brand name), which is part of a brand that can be pronounced or pronounced. Examples: Avon, Toyota, Disneyland, Pepsodent, and others.

2 Brand marks, which are part of a recognizable brand, but cannot be read or spoken. These brand marks are logos, symbols, colors, drawings, designs.

Factors - factors that underlie the brand name of a product include:

1. Giving a name based on the product creator.

Example: Estee Lauder Cosmetics, Orville Redenbacher popcorn

2. Giving a name by place

Example: Surabaya Plaza Hotel, British Airways, Sante Fe Cologne

3. Giving a name based on the name of the animal / bird

Example: Mustang automobiles, Kuda Mas cigarettes

4. Giving a name based on a particular object / object

Example: Apple computers

5. Giving a name based on the meaning / meaning of the product, which means the name explains the existence of marketable products. Example: Just Juice 
6. Giving a name based on the function or usefulness of the product

Example: Mop and Glo floor cleaner: floor cleaning product

\section{RESEARCH METHODS}

To answer this research used multiple regression analysis (Multiple Regression). Used to analyze the influence of independent variables Celebrity Endorser and Brand Image to the dependent variable that is Purchase Decision on Luwak White Coffee.

Information :

$\mathrm{Y}=$ Purchase Satisfaction

$=$ Constants

$=$ Regression coefficient

= Celebrity Endorser

$=$ Brand Image

$\mathrm{E}=$ error

In this study multiple linear regression analysis using SPSS 20.00 This method is done with the aim of finding correlation or influence between independent variable with dependent variable. With decision making based on the probability number, if the probability is less than 0.05 then the null hypothesis is rejected and the alternative hypethetic is accepted (Priyanto in aryati, 2015).

\section{DISCUSSION}

The results of the analysis based on the proving hypothesis shows that the Endorser celebrity variable has a significant positive effect on the decision to purchase Luwak White Coffee ". Means the consumer considers that the supporting factor in a product is very important such as packaging, taste enjoyment etc. is needed in white coffee products because this is a basic requirement that should not be left behind. This will increase consumer confidence in buying 
white coffee products. The result of analysis based on the proving hypothesis shows that the Endorser celebrity variable has a significant positive effect on decision to purchase Luwak White Coffee Client ". Means consumers assume that when the brand image is built on a white coffee mongoose is strong then consumers will feel confident in buying white coffee mongoose.

\section{CONCLUSION}

Brand Celebrity Endorser variable with value of t count 4,335 which value $\mathrm{t}$ sig. 0.006 means the sig value. 0.0006 is smaller than 0.07 then individual coefficients of celebrity Endorser variable have a positive effect significant to white civet purchasing decision coffee at luwak white coffee. Brand Image variables with t value of 7.543 which t sig value. 0.003 means sig value. 0.003 is smaller than 0.06 then individually coefficient variable of brand image have positive significant effect to purchase decision on luwak white coffee customers. At the value of $\mathrm{F}$ arithmetic 28.131 the value of $\mathrm{F}$ sig. 0,000 means the sig value. 0,000 smaller than 0.06 then collectively the coefficient of variables celebrity Endorser, brand association, and brand image have a positive effect significant to the purchase decision on white civet coffee mongoose.

\section{References}

Amirullah,. (2002). Perilaku Konsumen. Penerbit: Graha Ilmu. Yogyakarta.

Ardianto, Yuri. (2013). “Pengaruh Celebrity Endorser dan Brand Assosiation Keputusan Pembelian Shampoo Clear Men (Studi Kasus Iklan

Shampoo Clear Man Versi Cristian Ronaldo Tahun 2012 Pada Mahasiswa Universitas Negeri Yogyakarta)".

Hendri, Ma'ruf,. (2005). Pemasaran Ritel, Jakarta: PT Gramedia Pustaka Utama.

Kotler \& Amstrong. (2010). Dasar-Dasar Pemasaran. Jakarta: PT Indeks.

Kotler \& Keller. (2006). Manajemen Pemasaran, Edisi 12 jilid 1, Terjemahan

(Molan Benyamin). Indonesia: PT. Indeks. 
Silvera, David H. \& Austad Benedikte. (2004). Factors predicting the effectiveness of celebrityendorsement advertisements. University of Tromso, Tromso, Norway. Euripean Journal of Marketing, 38(11/12), pp: 1509-1526 